\title{
KAJIAN YURIDIS EFEKTIFITAS PENYELESAIAN KREDIT MACET MELALUI LELANG HAK TANGGUNGAN
}

\author{
Ayup Suran Ningsih \\ Fakultas Hukum, Universitas Negeri Semarang, Indonesia \\ Gedung K Kampus UNNES, Sekaran, Gunungpati, Semarang \\ Email: ayuupp@mail.unnes.ac.id
}

\begin{abstract}
In a debt agreement that includes a guarantee regulated in the Mortgage Law, the form of legal protection provided by the State through the Mortgage Law to the creditor is the authority to execute the object of the debtor's guarantee or auction. Implementation of the auction through the State Auction Institution, namely the Office of the State Assets and Auction Service (KPKNL). The purpose of writing this article is to find out the arrangement and implementation of mortgage auctions at KPKNL. The method used is empirical juridical, with the research location at KPKNL Semarang PMK No. 213/PMK.06/2020. Auction of Mortgage through $K P K N L$ is an effective solution for both parties in the case of debtors defaulting, because KPKNL applies regulatory procedures according to applicable regulations that protect the interests of both parties, debtors and creditors properly, which are guaranteed by regulations. The rights of creditors must be protected when the debtor defaults. Settlement of bad debts through auctions must be carried out as the final "ultimum remidium" step for debtors.
\end{abstract}

Keywords: Auction, Mortgage Right, Default, Bad Credit, KPKNL

\begin{abstract}
Abstrak
Dalam perjanjian hutang piutang yang menyertakan jaminan diatur oleh Undang-Undang Hak Tanggungan, suatu bentuk perlindungan hukum yang telah diberikan Negara melalui UndangUndang Hak Tanggungan kepada kreditur adalah wewenang untuk melakukan eksekusi objek jaminan debitur atau lelang. Pelaksanaan Lelang melalui Lembaga Lelang Negara dikenal sebagai Kantor Pelayanan Kekayaan Negara dan Lelang (KPKNL). Penulisan ini memiliki tujuan untuk mengetahui pengaturan dan pelaksanaan lelang hak tanggungan di KPKNL. Metode yang digunakan adalah yuridis empiris, dengan lokasi penelitian di KPKNL Semarang. Pelaksanaan Lelang Hak Tanggungan di KPKNL Semarang mengikuti ketentuan PMK No. 213/PMK.06/2020. Lelang Hak Tanggungan melalui KPKNL menjadi solusi efektif bagi kedua pihak dalam hal debitur wanprestasi, karena KPKNL menerapkan prosedur aturan sesuai peraturan yang berlaku yang melindungi kepentingan kedua pihak, debitur dan kreditur dengan baik, yang dijamin oleh Peraturan. Hak dari kreditur wajib untuk dilindungi ketika debitur wanprestasi. Penyelesaian kredit macet melalui lelang wajib dilakukan sebagai langkah terakhir "ultimum remidium" bagi debitur.
\end{abstract}

Kata kunci: Lelang, Hak Tanggungan, Wanprestasi, Kredit Macet, KPKNL 


\section{Latar Belakang}

Perkembangan zaman berbanding lurus dengan meningkatnya kebutuhan modal yang tersedia, yang terutama dapat diperoleh melalui suatu kegiatan kredit', tetapi tidak jarang dalam kegiatan perkreditan terjadi wanprestasi oleh debitur yang berimplikasi pada pengeksekusian objek jaminan yang dijaminkan oleh debitur kepada kreditur untuk mendapatkan dana tersebut. ${ }^{2}$ Eksekusi yang dilakukan oleh kreditur tidak terlepas dari upaya pemenuhan dan pengembalian hak kreditur. ${ }^{3}$ Kreditur dalam melaksanakan eksekusi tersebut haruslah melalui sebuah lembaga umum, yaitu lembaga lelang. Lembaga lelang ${ }^{4}$ merupakan lembaga hukum yang dewasa ini dibutuhkan oleh masyarakat luas. Lembaga lelang sendiri memiliki salah satu fungsi untuk melaksanakan lelang eksekusi apabila terjadi permasalahan antara kreditur dan debitur dalam lingkup jaminan.

Dalam perjanjian hutang piutang yang menyertakan jaminan, Suatu bentuk perlindungan hukum yang diberikan disediakan Negara melalui Undang-Undang Hak Tanggungan kepada kreditur adalah wewenang untuk melakukan eksekusi objek jaminan debitur. ${ }^{5}$ Pinjaman dapat dilakukan baik melalui lembaga perbankan maupun non perbankan, hampir setiap pinjaman yang diberikan oleh kreditur meminta agunan atau jaminan dari debitur. Jaminan merupakan bentuk protection atau perlindungan bahwa debitur harus menawarkan untuk menjamin pelunasannya untuk menjamin keamanan dan kepastian hukum, khususnya jika setelah jangka waktu yang diperjanjikan debitur tidak memenuhi perjanjian atau tidak mampu membayar utang sehingga terjadi wanprestasi. ${ }^{6}$ Jadi, untuk dapat melakukan peminjaman harus antara bank sebagai pihak kreditur dan nasabah sebagai pihak debitur disebut akad kredit atau perjanjian kredit. ${ }^{7}$ Di dalam memberikan kredit kepada masyarakat, Bank harus yakin bahwa dana yang dipinjamkan kepada debitur akan dikembalikan tepat waktu serta bunganya dan dengan syarat-syarat yang disepakati antara bank dan nasabah seperti

1 Ayup Suran Ningsih and Hari Sutra Disemadi, "Breach of Contract: An Indonesian Experience in Akad Credit of Sharia Banking," Ijtihad: Jurnal Wacana Hukum Islam dan Kemanusiaan 19, no. 1 (2019): 89-102.

2 Ayup Suran Ningsih, Duhita Driyah Suprapti, and Nurul Fibrianti, "The Importance of Applying the Membership Value Toward Savings and Loans Cooperatives in Indonesia," Sriwijaya Law Review 3, no. 25 (2019): 225-234, http://journal.fh.unsri.ac.id/index.php/sriwijayalawreview/article/view/235.

3 Supriadi Jufri, Anwar Borahima, and Nurfaidah Said, "Pelaksanaan Lelang Eksekusi Hak Tanggungan Melalui Balai Lelang," Jurnal Ilmiah Dunia Hukum (2020).

4 Maria Stephannie Halim, "PERLINDUNGAN HUKUM TERHADAP PEMILIK JAMINAN DALAM LELANG EKSEKUSI HAK TANGGUNGAN," Jurnal Hukum Bisnis Bonum Coтmune (2018).

5 REPUBLIK INDONESIA, Undang-Undang Nomor 4 Tahun 1996 Tentang Hak Tanggungan Atas Tanah Beserta Benda-Benda Yang Berkaitan Dengan Tanah, 1996.

6 Badriyah Harun, Penyelesaian Sengketa Kredit Bermasalah, Pustaka Yustisia, 2010.

7 Wilda Prima Putri, "Perlindungan Hukum Terhadap Bank Sebagai Pemegang Jaminan Kebendaan Terkait Pelunasan Hutang Oleh Debitor (Studi Kasus Putusan No.50/Pailit/2010/PN.Niaga.JKT.PST)," ADIL: Jurnal Hukum 9, no. 2 (May 2019): 35-60. 
yang tercantum dalam kontrak kredit. ${ }^{8}$ Menurut pokoknya, suatu jaminan yang tergolong dalam bergerak maupun yang tergolong sebagai tidak bergerak, bukanlah milik pribadi kreditur, karena suatu perjanjian utang atau suatu perjanjian kredit bukanlah suatu perjanjian penjualan yang mengakibatkan perpindahan kepemilikan. tetapi agunan tersebut digunakan untuk melunasi utangnya dengan cara yang dipersyaratkan oleh hukum yang berlaku, yaitu barang tersebut dijual secara pelelangan dimana produknya untuk melunasi utang debitur, dan apabila ada kelebihan, hasilnya akan dikembalikan kepada debitur.9 Salah satu bentuk jaminan yang banyak digunakan sebagai jaminan dalam kontrak kredit adalah hak tanggungan. Hak Tanggungan berdasarkan Undang - Undang No. 4 Tahun 1996 yaitu: ${ }^{10}$

" Hak Tanggungan atas tanah dan harta benda yang melekat pada tanah, yang selanjutnya disebut Hak Tanggungan, adalah suatu jaminan atas hak atas tanah berdasarkan Undang-undang Nomor 5 Tahun 1960 mengenai Peraturan Dasar Pokok-Pokok Agraria, pada dasarnya Undang-undang ketentuan prinsip-prinsip pertanian, dengan atau tanpa barang-barang lain berikut yang melekat pada tanah, untuk membayar hutang tertentu kepada kreditur lain."

Hak Tanggungan menjadi penting eksistensinya ketika banyak kebutuhan masyarakat terkait lembaga jaminan yang mengurusi segala pengaturan terkait jaminan yang dibebankan dengan benda tak bergerak. ${ }^{11}$ Maka hadirnya UndangUndang Hak Tanggungan No. 4 Tahun 1996 mengatur segala aspek didalamnya, salah satunya adalah terkait pembebanan hak tanggungan yang menjadi bagian penting dari pencapaian perjanjian yang diikatkan objek hak tanggungan sebagai agunan. Dijelaskan untuk dapat terlaksana suatu pembebanan terkait hak tanggungan yang sah maka harus memenuhi unsur yang ada pada Pasal 10, yang menjelaskan keseluruhan alur mulai dari pendaftaran hak tanggungan sampai dengan terbitnya sertifikat hak ttanggungan tersebut. Hak Tanggungan merupakan salah satu lembaga jaminan digunakan sebagai jaminan untuk membayar hutang peminjam.

Berdasarkan ketentuan Pasal 6 jo Pasal 20 ayat 1 huruf (a) UUHT, pelaksanaan hak tanggungan dapat dilakukan oleh tanggungan dalam pemerintahannya melalui

8 Ayup Suran Ningsih, “THE LEGAL PROTECTION FOR DEBTORS IN THE EXECUTION OF MORTGAGE AT THE SEMARANG STATE ASSETS AND AUCTION SERVICE OFFICE," Jurisdictie: Jurnal Hukum dan Syariah 12, no. 1 (2021): 86-103, http://ejournal.uin-malang.ac.id/index.php/jurisdictie/article/view/12112/ pdf.

9 Gatot Supramono, Perbankan Dan Masalah Kredit Suatu Tinjauan Yuridis (Jakarta: Djambatan, 1996).

10 REPUBLIK INDONESIA, Undang-Undang Nomor 4 Tahun 1996 Tentang Hak Tanggungan Atas Tanah Beserta Benda-Benda Yang Berkaitan Dengan Tanah.

11 Pandu Dwi Nugroho, "PELAKSANAAN LELANG TERHADAP OBYEK YANG DIBEBANI HAK TANGGUNGAN DALAM RANGKA MEWUJUDKAN KEADILAN PARA PIHAK," Rechtidee (2018). 
pelelangan umum. Artinya, pelaksanaan pelelangan menurut Pasal 6 UUHT adalah kewenangan yang diberikan undangundang kepada tanggungan pertama untuk melakukan pelelangan umum barang jaminan jika debitur ingkar janji. Dengan demikian, undang-undang memberi wewenang kepada kreditur untuk melaksanakan kewajibannya tanpa persetujuan salah satu pihak. Dengan adanya ketentuan tersebut maka harus ada perlindungan hukum terhadap objek hak tanggungan dalam proses lelang bagi debitur yang wanprestasi.

Hak Tanggungan memberikan posisi yang diprioritaskan Kepada pihak Kreditur sebagai pihak Pemegang Hak Tanggungan Kamus Oxford: "The lender in a mortgage, typically a bank, building society, or savings and loan association" Yang merupakan hak prioritas dalam pembayaran Debitur daripada hak kreditor lainnya. Jika Debitur sebagai hipotek Kamus Oxford: "The borrower in a mortgage, typically a homeowner". Cidera janji atau wanprestasi yang telah disepakati sebelumnya oleh kedua belah pihak, Kreditur, pemegang objek hak tanggungan, memiliki hak untuk menjual melalui lelang publik atas tanah yang digunakan sebagai jaminan sebagaimana dinyatakan dalam undangundang dan peraturan terkait, dengan hak untuk diprioritaskan daripada kreditor lainnya.

Eksekusi, dalam istilah hukum Belanda disebut sebagai executie atau uitvoering, secara etimologis, berarti pemberlakuan keputusan pengadilan. Seperti yang dinyatakan oleh Subekti, eksekusi adalah upaya pihak yang menang di pengadilan untuk mendapatkan haknya yang dijamin oleh hukum, dan memaksa pihak yang kalah di pengadilan untuk mematuhi apa yang dituntut oleh keputusan pengadilan. ${ }^{12}$ Eksekusi pada agunan sebagai objek pinjaman hak tanggungan, pada dasarnya, adalah pilihan terakhir yang diambil oleh Kreditur sebagai pemegang objek hipotek (mortgagee) ketika Debitur sebagai mortgagor terbukti gagal dalam membayar pinjaman uang.

Eksekusi hak tanggungan hanya dapat dilakukan jika Debitur terbukti tidak dapat memenuhi kewajiban pembayaran angsuran kredit atau utang atau pinjaman kepada Kreditur atas dasar persetujuan kredit atau perjanjian kredit atau perjanjian pinjaman oleh kedua pihak. Dalam posisi ini, Kreditur, dalam melaksanakan eksekusi terhadap Suatu objek hak tanggungan, harus patuh pada ketentuan Undang-Undang Hak Tanggungan Nomor 4 Tahun 1996 atas benda-benda yang berhubungan dengan tanah. ${ }^{13}$

Tentang eksekusi pada objek hak tanggungan atas agunan yang dijadikan sebagai jaminan Debitur kepada Kreditur, dalam Pasal 21 Ayat (1) ketentuan Undang-Undang Hak Tanggungan Nomor 4 Tahun 1996 atas benda-benda yang berhubungan dengan tanah (UU HT) telah diatur ada tiga cara eksekusi

12 \& Najib I. Ginati A., "Tinjauan Yuridis Eksekusi Hak Tanggungan Melalui Penjualan Di Bawah Tangan Sebagai Alternatif Penyelesaian Kredit Macet Di PD. BPR Bank Klaten.,” Jurnal Repertorium IV, no. 1 (2017): 34.

13 Catur Budi Dianawati and Amin Purnawan, "Kajian Hukum Jaminan Hak Tanggungan Yang Dilelang Tanpa Proses Permohonan Lelang Eksekusi Ke Ketua Pengadilan Negeri," Jurnal Akta (2017). 
yang mana Kreditur dapat mengambil salah satu langkah dalam melakukan eksekusi terhadap objek hak tanggungan Pertama, adalah parate eksekusi itu sendiri yang mana hak eksekusi ada pada Kreditur dalam melakukan eksekusi terhadap objek hak tanggungan, dengan melelangnya. Eksekusi seperti ini termasuk penyitaan eksekusi dari pihak Kreditur tanpa intervensi pengadilan. Kedua, adalah eksekusi oleh Kreditur dengan titel eksekutiorial. Dalam eksekusi ini, Kreditur tidak perlu mengajukan gugatan. Kreditur dapat menggunakan Sertifikat Hak Tanggungan sebagai dasar hukum dalam melaksanakan eksekusi terhadap objek hak tanggungan sebagai jaminan Debitur dalam berhutang pada Kreditur. Ini secara khusus diatur pada Pasal 14 dalam Pasal 14 Ayat (2) Undang-Undang Nomor 4 Tahun 1996 Tentang Hak Tanggungan Atas Tanah Serta Benda-Benda Yang Berkaitan Dengan Tanah dengan jelas menyatakan,

"Sertipikat Hak Tanggungan sebagaimana dimaksud pada ayat (1) memuat irah-irah dengan kata-kata" "DEMI KEADILAN BERDASARKAN KETUHANAN YANG MAHA ESA".

Berdasarkan irah-irah ini, dapat diartikan sertifikat memiliki wewenang eksekusi yang sama dengan wewenang putusan pengadilan yang mengikat secara hukum, sepertipengganti akta grosse hypotheek..$^{14}$ Acte grosse memiliki otoritas eksekusi yang merupakan penjualan pada objek sesuai dengan Hukum Acara Perdata, sebagaimana diatur dalam Pasal 224 H.I.R. (Herziene Inlandsch Reglement atau Revisi Regulasi Inlandsch) atau Pasal 258 RBg (Reglement tot Regeling van het Rechtswezen in de Gewesten Buiten Java en Madura atau Peraturan Kehakiman di Wilayah Jawa dan Madura). Lebih lanjut, hak eksekusi diatur pada Pasal 20 Ayat 20b atas Hak Tanggungan Tanah dan Undang-Undang Nomor 4 Tahun 1996, yang menyatakan bahwa suatu objek Hak tanggungan yang terjual melalui pelelangan umum tunduk pada prosedur yang ditetapkan dalam undang-undang yang mengatur pembayaran kembali hutang Debitur atas Kreditur melalui pembebanan hak tanggungan, yang berdasarkan pada prinsip Le droit de préférence, Kreditur memiliki prioritas $^{15}$ atau didahulukan pelunasannya daripada kreditur yang lain. Sertifikat Hak Tanggungan sebagaimana dimaksud pada ayat (2) mempunyai kekuatan eksekutorial yang sama dengan putusan pengadilan yang telah mempunyai kekuatan hukum tetap dan merupakan pengganti grosse acte Hypotheek sepanjang mengenai hak atas tanah. (Pasal 14 Ayat (3) UU HT).

Ketiga, adalah penjualan di bawah tangan. Pada prinsipnya, penjualan di bawah tangan ini didasarkan pada persetujuan kedua belah pihak, baik Debitur dan Kreditur untuk

14 Prof. Boedi Harsono S.H., "Tanah Sebagai Jaminan Kredit: Suatu Tinjauan Yuridis," Hukum dan Pembangunan (1989).

15 I Dewa Gede Agung Dhira Natsya Ora and Dewa Gde Rudy, "Kedudukan Lembaga Perbankan Sebagai Pembeli Lelang Eksekusi Hak Tanggungan Atas Jaminanya,” Acta Comitas (2021). 
kemudian mendapatkan harga yang tertinggi sehingga nantinya dari kesepakatan harga tersebut dapat saling menguntungkan satu sama lain, tidak hanya menguntungkan salah satu pihak saja.

Penjualan di bawah tangan hanya dapat dilakukan pada satu bulan setelah adanya pengumuman tertulis oleh Pemegang Hak Tanggungan atau Kreditur itu sendiri kepada debitur dan mengumumkannya paling tidak pada dua buah surat kabar yang diterbitkan di wilayah tempat para pihak yang terlibat di dalamnya berdomisili, juga harus tidak ada keberatan atau ketidakpuasan dari para pihak yang berkepentingan. ${ }^{16}$

Sesuai dengan ketentuan Pasal 26 UndangUndang Nomor 4 Tahun 1996 mengenai Hak Tanggungan atas tanah dan benda-benda yang Berhubungan Dengan Tanah, selama tidak ada peraturan yang mengatur tentang itu, dengan mengacu pada ketentuan berdasarkan Pasal 14 , peraturan terkait pelaksanaan hipotek yang berlaku pada saat tindakan ini diterapkan, termasuk pelaksanaan suatu eksekusi Hak Tanggungan yang diterapkan.

Berdasarkan ketiga jenis eksekusi yang diatur oleh peraturan perundang-undangan, artikel ini akan lebih khusus mengkaji terkait cara eksekusi yang pertama, yaitu melalui lelang atau parate eksekusi. Tujuan dari penulisan artikel ini untuk mengetahui secara yuridis efektifitas penyelesaian kredit macet melalui lelang hak tanggungan, tentu saja disini yang dimaksud dengan kredit macet adalah kredit macet dengan jaminan berupa hak tanggungan.

\section{Pembahasan}

\section{A. Tinjauan Yuridis terkait Kredit Macet}

Dalam pembahasan pada artikel ini akan lebih khusus membahas Hak Tanggungan yang dijadikan jaminan kredit perbankan, karena berdasarkan observasi penulis didapati bahwa peserta lelang Hak Tanggunggan di KPKNL Semarang berasal dari Kreditur Bank. Kredit dalam perbankan merupakan bisnis yang paling penting karena pendapatan terpenting perbankan adalah pendapatan dari kredit bisnis, terutama dalam bentuk bunga dan komisi. Ruang lingkup dari kredit sebagai kegiatan perbankan tidaklah semata-mata berupa kegiatan peminjaman kepada nasabah, tetapi sangatlah kompleks menyangkut keterkaitan unsur-unsur yang cukup banyak, salah satu diantaranya adalah terkait penyelesaian kredit yang terhambat.

Sesuai dengan ketentuan Pasal 8 (1) Undang-Undang Nomor 10 Tahun 1998 yang mengatur mengenai Perbankan dapat dilihat setidaknya debitur harus mempunyai itikad baik atau kemauan dan kemampuan untuk melunasi hutangnya. Apabila dikemudian hari pada saat jatuh tempo debitut tidak dapat melunasi hutangnya maka debitur telah melakukan wanprestasi. Prestasi yang telah dilakukan oleh kreditur, dalam hal ini 
bank, tidak diikuti dengan kontra prestasi yang seharusnya diterima oleh bank. Pasal 1238 Kitab Undang-Undang Hukum Perdata menegaskan: ${ }^{17}$

"Si berhutang adalah lalai bila ia dengan surat perintah atau dengan sebuah akta sejenis itu telah dinyatakan lalai, atau demi perikatannya sendiri menetapkan bahwa si berhutang akan harus dianggap lalai dengan lewatnya waktuyang ditentukan"

Dalam hal Debitur telah melakukan wanprestasi karena pada saat jatuh tempo pembayaran hutang, debitur tidak dapat melunasinya. Akibat-akibat yang harus diterima oleh debitur karena kelalaiannya berupa: Pembayaran kerugian yang diderita oleh kreditur atau biasa disebut ganti rugi; Pembatalan perjanjian atau pengakhiran perjanjian; Peralihan risiko membayar biaya perkara. $^{18}$

Meskipun demikian apabila dilihat lebih jauh ketentuan didalam KUHPerdata maka gugatan wanprestasi bukanlah merupakan solusi yang menguntungkan bagi kreditur. Pasal 1248 KUHPerdata berbunyi:

"Kalaupun wanprestasi itu karena penipuan oleh debitur, penggantian biaya, kerugian dan bunga hanya berkaitan dengan kerugian yang diderita debitur dan kehilangan keuntungan baginya, kami hanya memasukkan akibat langsung. ketidakpatuhan terhadap perjanjian."
Berdasarkan Pasal 1248 KUHPerdata diatas ganti rugi dibatasi hanya meliputi Kerugian yang dapat diperkirakan dan dihasilkan langsung dari wanprestasi. Dengan demikian, kreditur harus mencari solusi lain untuk memenuhi hak prestasinya.

Dasar Hukum yang dapat memberikan ruang lingkup kualitas kredit di industri perbankan yaitu Peraturan Bank Indonesia (PBI) No. 14/15/PBI/2012 yang mengatur mengenai Penilaian Kualitas Aset Bank Umum. Pasal 1 angka 5 mendefiniskan Kredit adalah sebagai berikut:19

"Pemberian kredit adalah pemberian uang atau permintaan sama dengan mendasarkan pada kontrak pinjaman atau kesepakatan antara bank dan pihak lain, yang mengharuskan peminjam untuk membayar kembali pinjaman setelah jangka waktu tertentu. jangka waktu tertentu dengan bunga, antara lain:

a. cerukan (overdraft), yaitu saldo giro negatif nasabah yang tidak dapat dilunasi pada akhir hari;

b. pengambilalihan tagihan dalam rangka kegiatan anjak piutang; dan

c. pemulihan atau pelunasan kredit dari pihak ketiga

Kualitas kredit ditentukan berdasarkan 3 (tiga) faktor penilaian yang sebagai berikut: Satu, prospek usaha; Dua, kinerja (performance) debitur; dan Tiga, kemampuan membayar. ${ }^{20}$ Peraturan Bank Indonesia (PBI)

17 Kitab Undang-Undang Hukum Perdata, n.d.

18 "PERLINDUNGAN HUKUM BAGI KREDITUR DALAM EKSEKUSI PERJANJIAN KREDIT DENGAN JAMINAN HAK TANGGUNGAN ATAS TANAH," LEX PRIVATUM (2020).

19 Bank Indonesia, Peraturan Bank Indonesia (PBI) Nomor 14/15/PBI/2012 Tentang Penilaian Kualitas Aset Bank Umum, 2012.

20 Ibid. 
Nomor 14/15/PBI/2012 mengatur secara khusus perihal klasifikasi debitur wanprestasi, lebih jelas diatur Debitur dapat dinyatakan wanprestasi apabila:

a. terjadi apabila tunggakan pokok dan/ atau bunga dan/atau piutang lain-lain dalam waktu 90 (sembilan puluh) hari meskipun Harta Produksi belum jatuh tempo pembayarannya;

b. tidak menerima pembayaran pokok dan/ atau bunga dan/atau piutang lain pada saat jatuh waktu dari Harta yang Dihasilkan; atau

c. atau kegagalan untuk memenuhi persyaratan selain dalam pembayaran pokok dan bunga, yang dapat mengakibatkan terjadinya wanprestasi.

PBI Nomor 14/15/PBI/2012 juga memberikan Klasifikasi kualitas kredit didefinisikan sebagai: Lancar, Perhatian Khusus, Kurang Lancar, Diragukan, atau Macet.

Kredit Macet termasuk dalam wanprestasi, penggolongan wanprestasi terhadap Kredit Macet pada lembaga perbankan ini terdapat beberapa jenis, yaitu sebagai berikut: ${ }^{21}$

1. Wanprestasi Pembayaran

Dalam hal ini Debitur dianggap gagal bayar jika ia gagal membayar kembali pokok atau bunga pinjaman pada tanggal jatuh tempo, atau lalai membayar biaya-biaya lain yang menjadi kewajibannya berdasarkan perjanjian kredit atau dokumentasinya yang terkait
2. Wanprestasi yang berhubungan dengan Representasi

Wanprestasi yang dokumen-dokumen dan jaminan-jaminan terkait, termasuk jaminan debitur. Mengenai keaslian dan keabsahan akta perusahaan serta terhadap dokumendokumen yang ada. Jika kemudian terbukti tidak benar, debitur dianggap wanprestasi, yaitu wanprestasi terhadap Representasi.

3. Wanprestasi yang berhubungan dengan Hal-hal yang Dilarang

Jenis wanprestasi ini dapat diperkirakan jika debitur melanggar salah satu dari yang sering diperinci dalam keadaan dimana debitur tidak dapat melaksanakan (negative covenant), yaitu perjanjian yang melarang penggabungan, pengambilalihan, peleburan, dan penjualan harta, dilarang menerima kredit lain, dilarang mengambil deviden, larangan melakukan perubahan-perubahan yang bersifat Corporate Changes, larangan melakukan transaksi kecuali transaksi biasa sehari-hari, larangan pergantian direksi atau pemegang saham, dan sejenisnya

4. Wanprestasi atas kewajiban lain-lain

Dalam bagian ini ditegaskan bahwa kegagalan debitur untuk memenuhi ketentuan lain dalam perjanjian kredit selain larangan debitur atau klausa representasi dan waran, juga dianggap sebagai pelanggaran kontrak. Biasanya, cacat akan berlaku setelah jangka waktu tertentu (misalnya 14 hari) setelah ditegur oleh kreditur, tetapi debitur tidak memperbaiki kesalahannya. 
Selain ke 4 jenis wanprestasi dalam dunia perbankan masih terdapat 7 jenis wanprestasi lainnya yaitu wanprestasi karena perizinan, wanprestasi silang, wanprestasi karena ada perubahan mendasar, wanprestasi karena klausula hukum, wanprestasi karena pailit, wanprestasi karena kelalaian terhadap perjanjian lain, dan wanprestasi dikarenakan keterlambatan dalam pelaksanaan perjanjian.

Otoritas Jasa Keuangan (OJK) selaku Lembaga yang mengatur dan mengawasi kinerja Bank memberikan pengaturan terkait langkah yang harus diambil dalam rangka penyelesaian Kredit Bermasalah. OJK mengeluarkan Peraturan Otoritas Jasa Keuangan (POJK) Nomor 42 / POJK.03/2017 tentang kewajiban menyusun dan melaksanakan kebijakan perkreditan bank atau kebijakan pembiayaan bagi bank umum

Pada prinsipnya Bank tidak mengharapkan terjadinya kredit macet atau permodalan yang tidak efisien, sehingga menentukan Kebijakan Pembiayaan Bank (KPB) secara tepat dan konsisten harus mencegah timbulnya masalah kredit atau keuangan. Untuk itu, seluruh jajaran Bank khususnya yang bergerak di bidang perkreditan atau keuangan perlu memiliki pandangan dan kesadaran yang sama dalam menangani kredit atau kredit macet dengan cara yang sama. sebagai berikut: ${ }^{22}$

1. Bank tidak memberikan wewenang atau menyembunyikan adanya Kredit bermasalah atau Pembiayaan yang tidak aktif;
2. Bank harus mendeteksi lebih awal adanya Kredit atau Pembiayaan yang bermasalah;

3. Penanganan pinjaman atau Pembiayaan yang mengalami permasalahan atau yang berpotensi menjadi Kredit dan Pembiayaan yang bermasalah juga harus diselesaikan sedini dan secepat mungkin;

4. Bank tidak menangani kredit macet dengan cara menaikkan plafond Kredit atau bunga utang dan memanfaatkan bunga utang atau biasa disebut dengan praktik plafondering Kredit; dan

5. Bank dilarang membuat pengecualian dalam menangani pinjaman atau pembiayaan yang tidak efisien, terutama untuk pinjaman atau pembiayaan yang gagal yang berkaitan dengan bank dan beberapa debitur terbesar yang ditentukan.

Dalam hal jumlah total Kredit atau Pembiayaan pemulihannya tergolong diragukan dan kerugiannya sebesar 7,5\% (tujuh koma lima persen) dari keseluruhan kredit atau keseluruhan pendanaan atau berdasarkan kriteria lain yang ditetapkan oleh Otoritas Jasa Keuangan utama. Direksi harus mengidentifikasi dan mengambil tindakan, paling kurang sebagai berikut:

1. Laporan Kredit atau Pembiayaan Tidak Aktif kepada Otoritas Jasa Keuangan Bank wajib segera menyampaikan laporan tertulis sebesar jumlah kredit

22 Otoritas Jasa Keuangan (OJK), Peraturan Otoritas Jasa Keuangan (POJK) Nomor 42 /POJK.03/2017 Tentang Kewajiban Penyusunan Dan Pelaksanaan Kebijakan Perkreditan Atau Pembiayaan Bank Bagi Bank Umum, 2017. 
atau pendanaan yang diklasifikasikan sebagai mencurigakan dan kerugian telah memenuhi kriteria.

2. Membentuk unit kerja atau kelompok kerja atau kelompok kerja untuk menangani pinjaman atau hibah yang tidak efisien. Bank harus membentuk unit kerja berupa kelompok kerja atau kelompok kerja atau yang serupa dengan Satuan Tugas (STK) yang bertanggung jawab atas penyelesaian pinjaman efektif atau pembiayaan bermasalah. Pejabat yang diangkat pada STK diangkat oleh direksi dan melapor kepada OJK. Bank mampu menentukan sendiri nama STK tersebut.

3. Penyusunan persiapan program penyelesaian kredit atau terkait kesulitan keuangan Bank harus mengembangkan program penyelesaian kredit atau Pembiayaan tidak aktif dan segera mengajukan kepada Otoritas Jasa Keuangan dengan pertimbangan hal-hal sebagi berikut: a. STK menyusun program penanganan pinjaman atau hibah yang tidak efisien untuk diajukan kepada direksi untuk disetujui. Program ini paling kurang meliputi: 1) tata cara penanggulangan utang atau pembiayaan yang tidak efisien, dengan memperhatikan ketentuan penanggulangan utang atau pembiayaan yang tidak efisien yang berlaku bagi perbankan; 2) perkiraan waktu untuk menyelesaikan; 3) perkiraan hasil kredit bermasalah atau pembayaran bermasalah; dan 4) sedapat mungkin mengutamakan penyelesaian Pinjaman atau Pembiayaan yang tidak efisien kepada pihak-pihak yang terkait dengan Bank dan kepada debitur utama. b. Penyelesaian kredit atau program hibah yang tidak efektif harus sesuai dengan KPB. Jika ada solusi terkait penyelesaian utang atau pembiayaan yang dianggap lebih efektif dari yang ditentukan dalam KPB, direksi dapat mengadopsi metode ini setelah disetujui direksi.

4. Melaksanakan program untuk mengatasi inefisiensi dalam kredit atau pembiayaan untuk menangani inefisiensi dalam kredit atau pembiayaan harus ditanggapi dengan serius, paling sedikit meliputi: a. Pelaksanaan ketentuan kredit macet atau pembiayaan dijamin sepenuhnya oleh STK berdasarkan program yang disetujui oleh Direksi. Dalam hal STK membutuhkan bantuan atau bantuan dari pejabat atau unit kerja lainnya, direksi harus memastikan bahwa bantuan atau bantuan tersebut dapat diperoleh dengan segera; b. STK secara berkala mengevaluasi kemajuan pemrosesan penyelesaian pinjaman atau masalah pendanaan dan melaporkan hasil evaluasi kepada direksi dengan tembusan kepada dewan pengawas dengan penjelasan yang diperlukan; dan c. hasil pelaksanaan program penyelesaian pinjaman atau wanprestasi yang dilaporkan oleh pengurus kepada Otoritas Jasa Keuangan. 
Untuk memastikan langkah penyelesaian kredit macet atau pembiayaan berbasis program diselesaikan dengan benar dan efisien, Otoritas Jasa Keuangan akan berkomunikasi langsung dengan STK setiap saat.

5. Mengevaluasi efektivitas program kredit atau Pembiayaan terbatas minimal setiap 6 (enam) bulan sekali setelah pelaksanaan program kredit atau pendanaan tidak aktif atau masa tenggang lainnya sebagaimana ditetapkan oleh Otoritas Jasa Keuangan, Bank akan mengevaluasi efektivitas penyelesaian kredit atau program pendanaan yang gagal, khususnya: a. Jika jumlah pinjaman atau kredit macet jauh lebih rendah dari perkiraan (tujuan) kredit atau financial distress sesuai dengan yang direncanakan, sedangkan penyelesaian kredit atau financial distress telah dilaksanakan secara optimal, STK merekomendasikan kepada Direksi untuk melakukan modifikasi atau perbaikan program kredit atau penyelesaian keuangan yang mengalami masalah. b. Hasil evaluasi terhadap efektivitas program penyelesaian Kredit atau Pembiayaan bermasalah dan setiap perubahan atau perbaikan terkait program tersebut harus segera dilaporkan kepada OJK.

Berdasarkan ketentuan yuridis yang telah diatur oleh OJK dan wajib ditaati oleh Bank, dapat disimpulkan bahwa Langkah melalukan Lelang terhadap objek jaminan yang dalam hal ini berupa Hak Tanggungan dapat dilakukan secara semena-mena, Bank wajib mengikuti prosedur yang telah ditentukan berdasarkan POJK Nomor 42 /POJK.03/2017 Tentang Kewajiban Penyusunan Dan Pelaksanaan Kebijakan Perkreditan Atau Pembiayaan Bank Bagi Bank Umum Sehingga, ketika Bank memutuskan untuk melakukan Lelang Hak Tanggungan, Bank sudah harus memastikan bahwa prosedur seperti yang telah diuraikan di atas telah dilaksanakan dengan baik.

Peraturan Menteri Keuangan (PMK) Republik Indonesia Nomor 213/PMK.06/2020 mengatur mengenai Petunjuk Pelaksanaan Lelang

Dasar hukum Pelaksanaan Lelang yang dilakukan oleh KPKNL melalui lelang.go.id saat ini adalah berdasarkan PMK No 213/ PMK.06/2020 yang mengatur mengenai Petunjuk Pelaksanaan Lelang, dimana Peraturan Menteri tersebut tersebut menjadi pedoman teknis pelaksanaan lelang, termasuk untuk lelang Hak Tanggungan. PMK No 213/PMK.06/2020 diundangkan untuk ${ }^{23}$ meningkatkan pelayanan guna mencapai efisiensi, transparansi, akuntabilitas, kesederhanaan, modernitas, dan legal, serta untuk memenuhi perkembangan pelaksanaan lelang.

PMK No 213/PMK.06/2020 memberikan pengertian Lelang dalam Pasal 1 angka 1 yang mengatur sebagai berikut: 
"Lelang ialah menjual barang kepada umum dengan harga secara tertulis dan/atau lisan, menambah atau mengurangi untuk mencapai harga tertinggi sebelum nya telah diberikan pengumuman lelang."

Selain mendefinisikan secara jelas ruang lingkup dari Lelang, PMK No 213/ PMK.06/2020 juga menggolongkan Lelang dalam 4 golongan sebagai berikut: ${ }^{24}$

Lelang Eksekusi adalah pelelangan untuk pelaksanaan putusan Pengadilan, dokumen lain yang dapat dipersamakan dengan itu dan/ atau untuk pelaksanaan ketentuan undangundang.

Lelang Noneksekusi Wajib adalah Lelang untuk menjual barang sesuai dengan undangundang melalui pelelangan.

Lelang Noneksekusi Sukarela adalah Lelang dengan tujuan untuk menjual harta milik pribadi, orang perseorangan, atau badan hukum/usaha yang dilelang secara sukarela. Lelang Noneksekusi Sukarela Terjadwal Khusus yang selanjutnya disebut dengan pelelangan barang bergerak tidak sukarela yang waktunya ditentukan oleh Penyelenggara lelang yang ditentukan dengan cara tertentu menurut kebiasaan dan direncanakan.

Lelang Hak Tanggungan atas kredit macet termasuk dalam golongan Lelang Eksekusi.

PMK No 213/PMK.06/2020 memberikan ketentuan baru terkait kehadiran peserta, yaitu dapat dengan dan tanpa kehadiran peserta. Lelang Dengan Kehadiran Peserta merupakan ${ }^{25}$ Lelang yang dapat dihadiri oleh Peserta Lelang baik secara langsung di tempat pelelangan atau melalui media elektronik yang memungkinkan Peserta Lelang saling melihat dan mendengar secara langsung selama pelelangan. Lelang tanpa peserta adalah ${ }^{26}$ Lelang di mana para Peserta Lelang tidak hadir secara langsung di tempat pelaksanaan lelang dilakukan atau dapat melalui Aplikasi Lelang yang disebut sebagai Platform e-Marketplace Auction yaitu melalui lelang.go.id.

Penyelenggara lelang tidak hanya dilakukan oleh KPKNL namun juga Balai Lelang swasta dan Kantor Pejabat Lelang Kelas II juga dapat melaksanakan Lelang sesuai dengan ketentuan. Balai Lelang memiliki wewenang melaksanakan Lelang Noneksekusi Sukarela atas permintaan dari Penjual sedangkan Kantor Pejabat Kelas II memiliki wewenang dalam menyelenggarakan Lelang Noneksekusi Sukarela atas permintaan Penjual atau Balai Lelang sebagai kuasa dari Penjual.

Tata cara pengajuan Permohonan Lelang berdasarkan Pasal 26 PMK No 213/ PMK.06/2020 adalah sebagai berikut:

1. Permintaan Lelang diajukan secara tertulis oleh pemohon lelang kepada Penyelenggara Lelang sesuai dengan jenis lelang dengan spesifikasinya.

2. Dalam hal penjual merupakan unit internal KPKNL, permohonan lelang sebagaimana dimaksud pada ayat 
(1) harus diajukan oleh pejabat yang berwenang sesuai dengan organisasi dan tata kerja DJKN kepada kepala departemen KPKNL yang bersangkutan.

3. Pengajuan permintaan lelang sebagaimana diatur pada ayat (1) dapat dilakukan dengan melalui aplikasi lelang.

4. Dalam hal permohonan lelang diajukan sebagaimana dimaksud pada ayat (3) dan dokumen lelang telah diverifikasi secara digital, maka permohonan dan dokumen lelang yang asli harus sudah diterima oleh pimpinan KPKNL paling lambat 14 (empat belas) jam kerja. hari sejak tanggal pernyataan final.

5. Dalam pelelangan untuk pelaksanaan putusan terhadap benda sitaan sebagaimana diatur dalam Pasal 45 KUHAP berupa ikan hasil tindak pidana penangkapan ikan, permintaan lelang dan surat berupa dokumen persyaratan lain dapat diajukan terlebih dahulu penawaran sebagaimana dimaksud pada ayat (1) oleh penjual kepada Kepala Departemen KPKNL melalui fax atau email (email).

6. Asli surat permohonan berikut dokumen persyaratan lelang sebagaimana dimaksud pada ayat (5) harus disampaikan kepada Kepala KPKNL untuk mendapat persetujuan dari Pejabat Lelang sebelum memulai lelang.

7. Tata cara pengajuan permintaan pelelangan dan dokumen penawaran sebagaimana dimaksud pada ayat (1), tercantum dalam huruf $\mathrm{A}$ dan huruf $\mathrm{B}$ terlampir merupakan satu kesatuan yang tidak terpisahkan dari Peraturan Menteri ini.

Dalam hal sebelum pelelangan benda yang digadaikan ada permintaan dari pihak selain debitur/pemegang jaminan dan/atau pasangan debitur/pemegang jaminan sehubungan dengan kepemilikan benda yang akan dilelang, pelelangan berdasarkan berdasarkan yang diatur Pasal 6 Undang-Undang Hak Tanggungan tidak dapat dilaksanakan. ${ }^{27}$ Jadi, ketika Debitur tersebut merasa bahwa Proses Lelang yang diajukan oleh Kreditur tidak sesuai dengan ketentuan maka Debitur dapat mengajukan gugatan ke Pengadilan. Bukti Surat Register Gugatan yang akan menjadikan dasar Lelang Eksekusi terhadap hak Tanggungan ditunda atau diberhentikan.

Selain kreditur, pihak lain juga dapat mengajukan gugatan atas Lelang Eksekusi. Pihak lain tersebut antara lain:

1. Pihak-pihak selain debitur/penjamin dan/ atau pasangan debitur/penjamin terhadap harta benda sesuai yang dimaksud pada ayat (1) meliputi:

a. ahli waris yang sah, orang yang perbuatannya sehubungan dengan proses penetapan hak tanggung jawab dilakukan setelah ahli waris adalah pemiliknya adalah jaminan kematian dengan bukti yang sah;

b. pihak lain yang dokumen kepemilikannya tidak berkaitan dengan hak tanggungan; atau 
c. pihak menandatangani perjanjian pembelian/penjualan/aliansi yang diaktakan sebelum penetapan hak tanggungan.

Pembatalan sebelum Lelang dapat dilakukan dengan Permintaan dari Penjual dan Putusan atau Penetapan dari Lembaga Peradilan, atau hal lain yang akan diatur dalam PMK ini. Penulis mencermati bahwa Petunjuk Teknis yang diatur oleh Negara melalui PMK No 213/PMK.06/2020 sangat komprehensif dan tidak hanya melindungi Kreditur namun Debitur juga terlindungi Hak untuk memperoleh keadilannya. Pengajuan Permohonan Lelang dilakukan dengan prosedur taat prinsip serta Lelang dapat diberhentikan dan dibatalkan sebelum lelang, tentunya setelah memenuhi ketentuan yang diatur dalam PMK tersebut di atas. Tentu saja hal ini sangat baik bagi para pihak.

Berikut adalah dokumen persyaratan dalam pengajuan permohonan Lelang Hak Tanggungan berdasarkan PMK No 213/ PMK.06/2020:

\section{a. Dokumen Persyaratan Umum}

Sehubungan dengan Surat permohonan lelang, harus disertai dengan dokumen umum yang diperlukan yang diajukan pada saat permintaan lelang, sebagai berikut:

1) salinan/fotokopi keputusan penunjukan penjual/Surat Tugas Penjual/Surat Kuasa Penjual, kecuali Pemohon Lelang adalah perseorangan;

2) daftar item untuk dilelang, batas nilai dan uang untuk jaminan.

3) surat persetujuan dari pihak yang memiliki hak pengelolaan atau hak milik dalam hal pelelangan tanah dan/atau pekerjaan konstruksi dengan pekerjaan penunjang berupa hak guna bangunan atau hak guna tanah dengan hak pengelolaan atau hak milik;

4) Keterangan tertulis yang diperlukan untuk menyerahkan/menyetorkan hasil lelang berupa: a) kode Mata Anggaran Penerimaan (MAP), apabila hasil bersih lelang telah memenuhi ketentuan, harus disetorkan langsung oleh Bendahara Penerimaan ke Kas Negara; atau b) nomor rekening penjual atau surat pernyataan bermaterai lengkap dari penjual yang menerangkan bahwa ia tidak memiliki rekening khusus dan bersedia untuk mengambil atau menerima hasil bersih lelang dalam bentuk cek tunai atas nama Pejabat Penjual, jika hasil bersihnya harus diserahkan kepada Pemohon Lelang;

5) keterangan berupa Nomor Pokok Wajib Pajak (NPWP) peserta lelang dalam hal objek lelang adalah milik pribadi, badan hukum, atau badan usaha;

6) pernyataan penjual tentang persyaratan lelang tambahan (jika ada), sejauh tidak bertentangan dengan peraturan perundang-undangan, khususnya: a) jangka waktu bagi Peserta Lelang untuk diperbolehkan melihat, meneliti secara fisik barang yang akan dilelang; b) jangka waktu pembeli menarik Barang; dan/atau c) jadwal lelang (aanwijzing), dijelaskan kepada peserta lelang terlebih 
dahulu; d) kondisi khusus yang biasanya diimplementasikan dalam pelaksanaan penjualan barang tak berwujud, di mana pokok lelang adalah hak fisik.

7) surat pernyataan penjual tentang syarat lelang tambahan di luar yang diatur dalam angka 6 (jika ada) serta peraturan berlaku untuk penjual dan/atau undang-undang dan peraturan yang mendukungnya;

8) pernyataan/sertifikat penjual bahwa benda lelang berada di bawah penguasaan fisik penjual, dalam hal benda lelang merupakan barang milik orang perseorangan;

9) foto objek atau barang lelang; dan

10) Bukti Pembayaran Biaya Pendaftaran Lelang, untuk Pasal 6 UUHT terkait Lelang Eksekusi Pengadilan, dan Lelang Eksekusi Harta Pailit.

Terkait dengan legalisasi maka Dokumen penawaran dalam bentuk eksemplar harus dilampiri dengan legalisasi atau terdapat tulisan "fotokopi sesuai dengan aslinya" juga disertai tanda tangan dari Penjual.

\section{B. Pelaksanaan Lelang Hak Tanggungan}

Lelang merupakan proses yang dimulai dari seseorang yang akan menjual suatu barang hingga saat terjadinya persetujuan harga atau hingga lelang dihentikan karena tidak mencapai batas harga yang diinginkan.
Pelaksanaan lelang barang jaminan merupakan salah satu bentuk pelaksanaan lelang yang diatur dalam aturan pelaksanaan lelang. Lelang jaminan tergolong sebagai lelang eksekusi wajib yang pelaksanaannya didasari dengan adanya suatu mekanisme tertentu berupa perjanjian pembiayaan yang dilakukan untuk mendapatkan sejumlah dana melalui pemberian kredit yang diberikan kreditur kepada debitur. ${ }^{28}$ Lelang jaminan merupakan lelang eksekusi wajib yang dilaksanakan di KPKNL sebagai tempat yang sah untuk dilakukan lelang jaminan.

Jaminan menjadi salah satu aspek yang penting untuk dapat memberikan perlindungan kemungkinan risiko yang dapat timbul dalam pemberian kredit dari kreditur kepada debitur. Jaminan yang diberikan seorang debitur dapat berupa benda atau barang yang memiliki nilai jual sehingga apabila terjadi wnprestasi dengan tidak dipenuhinya pembayaran atas dana yang dipinjam debitur, seorang kreditur berhak atas benda jaminan tersebut. Dalam perjanjian peminjaman dana yang didasari atas kesepakatan antara pihak debitur dan kreditur selaku pihak-pihak yang berhubungan dalam peminjaman uang tersebut timbul suatu kewajiban debitur untuk menyerahkan jaminan kepada kreditur. ${ }^{29}$ Penggunaan Lembaga Hak Tanggungan oleh lembaga keuangan sebagai suatu jaminan atas kredit dari pihak debitur untuk pelunasan hutang lebih memberikan

28 Saya Haprabu. Penjualan Lelang Barang Jaminan Hak Tanggungan Menurut Perspektif Hukum Islam. Jurnal Repertorium Volume IV Nomor 1, Januari-Juni 2017. Hlm 55.

29 Catur Budi Dianawati dan Amin Purnawan. Kajian Hukum Jaminan Hak Tanggungan Yang Dilelang Tanpa Proses Permohonan Lelang Eksekusi Ke Ketua Pengadilan Negeri. Jurnal Akta Vol. 4 No. 2 Juni 2017 : 125 132. HIm 126. 
rasa aman dalam hal pemberian kredit, bila dibandingkan dengan ketentuan mengenai adanya jaminan berdasarkan Kitab UndangUndang Hukum Perdata Pasal 1131.

Hak tanggungan atas tanah dan harta benda yang berkaitan dengannya, yang selanjutnya disebut hak tanggungan, adalah jaminan bergerak yang dikenakan atas hak atas tanah menurut ketentuan undang-undang nomor 5 tahun 1960 tentang Peraturan Dasar versi Pokok-Pokok Pertanian, dengan atau tanpa badan-badan lain berikut, suatu kesatuan tanah, untuk membayar utang-utang tertentu, menciptakan kedudukan istimewa bagi kreditur-kreditur tertentu di atas utangutang lain kreditur-kreditur lainnya.. ${ }^{30}$ Debitur merupakan orang yang melakukan peminjaman dana atau berhutang kepada kreditur, dimana seorang kreditur dapat berupa bank atau perseorangan, dengan memberikan suatu jaminan yang disepakati kedua belah pihak.

Pengikatan suatu jaminan dengan tanggungan dilakukan apabila seorang debitur yang mendapatkan kredit dari sebuah bank selaku kreditur menjadikan barang tidak bergerak yang berupa tanah sebagai jaminan, dalam hal ini disebut hak atas tanah. Jaminan yang diterima kreditur dari seorang debitur diperbolehkan berupa hak atas tanah atau hak milik. ${ }^{31}$ Dalam suatu perjanjian peminjaman dana pada dasarnya dapat terjadi setelah adanya persetujuan antara kedua pihak yang bersangkutan dalam perjanjian tersebut yaitu pihak kreditur dan debitur. Seorang debitur disebut telah melakukan wanprestasi apabila tidak memenuhi suatu hal yang telah diperjanjikan sebelumnya dalam perjanjian yang dibuat dengan pihak kreditur, yang disebut juga dengan cidera janji. ${ }^{32}$

Terjadinya wanprestasi dapat berupa sebagian atau secara keseluruhan prestasi yang tidak dipenuhi oleh debitur. Dalam perjanjian kredit, yang disertai dengan Hak Tanggungan, wanprestasi dapat diartikan suatu keadaan dimana debitur sudah tidak memiliki kemampuan atau tidak memiliki itikad baik untuk membayar kewajiban ${ }^{33}$ terhadap kreditur sehingga jaminan yang telah dibebankan Hak Tanggungan dijual atau pada umumnya dilakukan lelang kepada pihak lain untuk dapat melunasi sejumlah pinjaman yang seharusnya didapat oleh kreditur. KPKNL merupakan tempat melaksanakan pelelangan eksekusi atas Hak Tanggungan berdasarkan Peraturan terkait Lelang (Vendu Reglement stb 1908-189) sama dengan aturan lelang umum di Indonesia (Reglement op de openbare

30 Pasal 1 Angka 1 Undang-Undang Nomor 4 Tahun 1996 Tentang Hak Tanggungan Atas Tanah Beserta BendaBenda yang Berkaitan dengan Tanah.

31 Suhaila Zulkifli. Tinjauan Tentang Pelaksanaan Lelang Atas Agunan Hak Tanggungan Dalam Perkara Kredit Macet ( Studi Putusan Nomor 86/PDT/2015/PT.MDN). Jurnal Hukum Kaidah. Hlm 98.

32 Edim Totonta Bangun. Tinjauan Yuridis Terhadap Jaminan Fidusia Yang Dilelang Tidak Melalui Badan Lelang Negara (Study Pada Pt. Kembang 88 Multifinance). Hlm 4.

33 Begiyama Fahmi Zaki. Kepastian Hukum Dalam Pelelangan Objek Hak Tanggungan Secara Online. Fiat Justisia Journal of Law Volume 10 Issue 2, April-June 2016. Hlm 373. 
verkoopengen in Indonesia). ${ }^{34}$ Dijelaskan dalam Pasal 1 Peraturan Lelang (Vendu Reglement stb 1908-189) bahwa pelaksanaan lelang di muka umum di Indonesia, termasuk Pelelangan dalam pelaksanaan eksekusi oleh Pengadilan Negeri diharuskan untuk dilaksanakan oleh KPKNL.

Dalam pelaksanaan lelang terdapat asasasas yang saling berkaitan dengan unsur-unsur lelang. Asas dan unsur yang saling berkaitan tersebut tidak boleh ada yang terlewat dan harus ada saat pelaksanaan lelang, sehingga in menjadi kewajiban KPKNL untuk memastikan saat pelaksanaan berjalan sesuai unsur serta asas pelaksanaan lelang. ${ }^{35}$

Untuk menerapkan parate eksekusi, Kreditur dapat datang ke Kepala Kantor Lelang dan meminta pelelangan terhadap objek hak tanggungan dengan mengirimkan permintaan lelang secara tertulis. Secara khusus, permintaan lelang tertulis tersebut ditujukan kepada Kepala KPKNL. Nantinya, pihak KPKNL akan memeriksa semua dokumen yang disyaratkan, yang telah diserahkan oleh pihak bank yang dalam hal ini juga berkedudukan sebagai Kreditur. Setelah memeriksa semua dokumen tersebut, selanjutnya KPKNL akan mengeluarkan jadwal pelaksanaan lelang kepada pihak bank secara tertulis.

Dalam pengeksekusian objek hak tanggungan yang umumnya berupa hak atas tanah, SKT (Surat Keterangan Tanah) atau Badan Pertanahan Nasional yang berdomisili di sekitar domisili Kreditur juga diperlukan. Setelah itu, pihak Bank akan mengeluarkan pengumuman lelang dengan memberikan pengumuman pertama, di mana pengumuman dipublikasikan di surat kabar atau pengumuman dipublikasikan di tempat yang mudah ditemui oleh publik dan dibaca oleh publik. Pengumuman kedua, harus dipublikasikan oleh surat kabar harian. Setelah melakukan pelelangan, Kreditor harus memberi tahu Debitur, sebagai pihak yang cidera janji berkenaan dengan tanah yang akan dilelang oleh Kreditur guna pelunasan hutang Debitur. Sehingga, pelelangan dapat diselesaikan pada saat jadwal yang telah ditentukan. Lelang akan dilaksanakan oleh Pejabat Lelang yang ditugaskan oleh Kepala KPKNL. Jika Pejabat Lelang telah menemukan penawar dengan harga tertinggi, penawar harus membayar paling lambat tiga hari setelah tanggal diadakannya pelelangan.

Pemenang Lelang harus membayar sesuai dengan harga yang terbentuk dalam lelang setelah dikurangi dengan nilai jaminan lelang yang telah disetorkan sebelumnya. Setelah menerima pembayaran dari pemenang lelang, bendahara KPKNL akan mengembalikan uang lelang ke bank setelah dikurangi masing-masing 5\% (lima persen) pajak

34 Catur Budi Dianawati dan Amin Purnawan. Kajian Hukum Jaminan Hak Tanggungan Yang Dilelang Tanpa Proses Permohonan Lelang Eksekusi Ke Ketua Pengadilan Negeri. Jurnal Akta Vol. 4 No. 2 Juni 2017 : 125 132. Hlm 130.

35 Permata Arina Iasya Landina, dkk. Pelaksanaan Lelang Atas Barang Milik Daerah Melalui Internet (E-AUCTION) Oleh Kantor Pelayanan Kekayaan Negara Dan Lelang (KPKNL) Semarang. Diponegoro Law Review Volume 5, Nomor 2, Tahun 2016. Hlm 7. 
penjualan dan $1 \%$ biaya lelang penjual (satu persen) dari nilai lelang. Setelah itu bank akan memperhitungkan hasil penjualan lelang objek jaminan hak tanggungan yang dijaminkan oleh debitur tersebut guna menyelesaikan semua kewajiban debitur kepada bank sebagai pihak kreditur, termasuk pokok pinjaman, bunga, denda dan biaya lainnya. Atas pelunasan ini, jika ditemukan masih ada kelebihan atau sisa dari jumlah hasil penjualan tersebut, maka bank harus mengembalikan kelebihan jumlah hasil penjualan tersebut ke tangan debitur. ${ }^{36}$

Pinjaman yang memberikan jaminan berupa Hak Tangunggan adalah keadaan yang melibatkan baik Pemberi Pinjaman yang juga disebut sebagai Kreditur sebagai pihak yang memberikan uang tunai kepada Peminjam atau Debitur yang timbul dari dijaminkannya properti si Peminjam sebagai jaminan, danjuga Peminjam atau Debitur sebagai pihak yang memiliki tanggung jawab dalam pembayaran kembali uang tunai yang dipinjamnya dari Pemberi Pinjaman atau Kreditur yang timbul dari pembebanan hak tanggungan atas harta benda milik Debitur. ${ }^{37}$ Tentang hak tanggungan itu sendiri Negara memberikan kepastian hukum melalui diundangkannya UndangUndang Hak Tanggungan yaitu UndangUndang Nomor 4 Tahun 1996 tentang Hak Tanggungan atas Tanah Dan Benda-Benda Yang Berhubungan Dengan Tanah. Dalam hak tanggungan, pihak-pihak yang harus terlibat adalah Debitur sebagai Peminjam, Kreditur sebagi Pemberi Pinjaman, Notaris sebagai pembuat APHT, dan Pihak Kantor Pertanahan. Bukti Pembebanan hak tanggungan atas tanah adalah dikeluarkannya Sertifikat Hak Tanggungan. Tentang parate eksekusi tidak memerlukan intervensi dari pengadilan, tetapi hanya perlu keputusan sendiri dari Kreditur dengan alasan cidera janji yang dilakukan oleh Debitur dalam melakukan pelunasan hutangnya dan KPKNL untuk pelelangan objek hak tanggungan.

\section{Penutup}

Hak Tanggungan didefinisikan sebagai salah satu lembaga jaminan yang banyak digunakan oleh masyarakat. Pemenuhan hak kewajiban antara penanggung dan tertanggung adalah suatu perbuatan hukum yang wajib dipenuhi oleh para pihak. Wanprestasi adalah suatu keniscayaan yang terjadi antara para pihak, terutama oleh tertanggung atau debitur. Salah satu solusi yang Ditentukan oleh Undang-Undang Hak Tanggungan jika debitur wanprestasi adalah pelaksanaan Lelang melalui Lembaga Lembaga Lelang Negara. Lelang Hak Tanggungan melalui KPKNL adalah solusi efektif bagi kedua pihak dalam hal debitur wanprestasi, karena KPKNL menerapkan prosedur aturan sesuai peraturan yang berlaku yang melindungi kepentingan kedua pihak, debitur dan kreditur Kredit Bermasalah di PT Bank Permata Tbk" (Jakarta: Universitas Indonesia, 2011), pp. 66-67.

37 Lastuti Abubakar, "Implementasi Prinsip Kehati-Hatian Melalui Kewajiban Penyusunan Dan Pelaksanaan Kebijakan Perkreditan Atau Pembiayaan Bank," Rechtidee 13, no. 1 (June 2018): 62-81. 
dengan baik, yang dijamin oleh Peraturan. Berdasarkan ketentuan yuridis yang telah diatur oleh OJK dan wajib ditaati oleh Bank, dapat disimpulkan bahwa Langkah melalukan Lelang terhadap objek jaminan yang dalam hal ini berupa Hak Tanggungan dapat dilakukan secara semena-mena, Bank wajib mengikuti prosedur sebagaimana diundangkan melalui POJK Nomor 42 / POJK.03/2017 yang mengatur mengenai Kewajiban Menyusun dan Melaksanakan Kebijakan Perkreditan Bank atau Kebijakan Pembiayaan Bagi Bank Umum Sehingga, ketika Bank memutuskan untuk melakukan
Lelang Hak Tanggungan, Bank sudah harus memastikan bahwa prosedur seperti yang telah diuraikan di atas telah dilaksanakan dengan baik. Lelang Hak Tanggungan ini berdasarkan penelitian yang dilakukan penulis, dilakukan dengan menerapkan asas "Ultimum Remidium" artinya pengajuan lelang Hak Tanggungan oleh Kreditur layaknya jalan terakhir yang ditempuh setelah melakukan beberapa prosedur sebelumnya. PMK No 213/ PMK.06/2020 tentang Petunjuk Teknis dalam Pelaksanaan Lelang telah sesuai dengan Undang-Undang Hak Tanggungan terkait dengan Lelang Eksekusi Hak Tanggungan.

\section{DAFTAR PUSTAKA}

\section{Buku}

S.H., Prof. Boedi Harsono. "Tanah Sebagai Jaminan Kredit: Suatu Tinjauan Yuridis." Hukum dan Pembangunan (1989).

Harun, Badriyah. Penyelesaian Sengketa Kredit Bermasalah. Pustaka Yustisia, 2010.

Harsono, Boedi. "Tanah Sebagai Jaminan Kredit." Jurnal Hukum \& Pembangunan (2017).

Jurnal

Abubakar, Lastuti. "Implementasi Prinsip Kehati-Hatian Melalui Kewajiban PenyusunanDanPelaksanaanKebijakan Perkreditan Atau Pembiayaan Bank." Rechtidee 13, no. 1 (June 2018): 62-81.
Dianawati, Catur Budi, and Amin Purnawan.

"Kajian Hukum Jaminan Hak Tanggungan Yang Dilelang Tanpa Proses Permohonan Lelang Eksekusi Ke Ketua Pengadilan Negeri.” Jurnal Akta (2017).

Ginati A., \& Najib I. "Tinjauan Yuridis Eksekusi Hak Tanggungan Melalui Penjualan Di Bawah Tangan Sebagai Alternatif Penyelesaian Kredit Macet Di PD. BPR Bank Klaten.” Jurnal Repertorium IV, no. 1 (2017): 34.

Halim, MariaStephannie. "PERLINDUNGAN HUKUM TERHADAP PEMILIK JAMINAN DALAM LELANG EKSEKUSI HAK TANGGUNGAN." Jurnal Hukum Bisnis Bonum Commune (2018). 
Jufri, Supriadi, Anwar Borahima, and Nurfaidah Said. "Pelaksanaan Lelang Eksekusi Hak Tanggungan Melalui Balai Lelang." Jurnal Ilmiah Dunia Hukum (2020).

Nasution, Alvin Hamzah. "FUNGSI PERLINDUNGAN OTORITAS JASA KEUANGAN TERHADAP NASABAH DEPOSAN." JUPIIS: JURNAL PENDIDIKAN ILMU-ILMU SOSIAL (2017).

Ningsih, Ayup Suran. "THE LEGAL PROTECTION FOR DEBTORS IN THE EXECUTION OF MORTGAGE AT THE SEMARANG STATE ASSETS AND AUCTION SERVICE OFFICE.” Jurisdictie: Jurnal Hukum dan Syariah 12, no. 1 (2021): 86-103. http://ejournal.uin-malang.ac.id/index. php/jurisdictie/article/view/12112/pdf. Ningsih, Ayup Suran, and Hari Sutra Disemadi. "Breach of Contract: An Indonesian Experience in Akad Credit of Sharia Banking." Ijtihad: Jurnal Wacana Hukum Islam dan Kemanusiaan 19, no. 1 (2019): 89-102.

Ningsih, Ayup Suran, Duhita Driyah Suprapti, and Nurul Fibrianti. "The Importance of Applying the Membership Value Toward Savings and Loans Cooperatives in Indonesia." Sriwijaya Law Review 3, no. 25 (2019): 225-234. http://journal.fh.unsri.ac.id/index.php/ sriwijayalawreview/article/view/235.
Nugroho, Pandu Dwi. "PELAKSANAAN LELANG TERHADAP OBYEK YANG DIBEBANI HAK TANGGUNGAN DALAM RANGKA MEWUJUDKAN KEADILAN PARA PIHAK.” Rechtidee (2018).

Ora, I Dewa Gede Agung Dhira Natsya, and Dewa Gde Rudy. "Kedudukan Lembaga Perbankan Sebagai Pembeli Lelang Eksekusi Hak Tanggungan Atas Jaminanya." Acta Comitas (2021).

Prima Putri, Wilda. "Perlindungan Hukum Terhadap Bank Sebagai Pemegang Jaminan Kebendaan Terkait Pelunasan Hutang Oleh Debitor (Studi Kasus Putusan No.50/Pailit/2010/PN.Niaga. JKT.PST).” ADIL: Jurnal Hukum 9, no. 2 (May 2019): 35-60.

Supramono, Gatot. Perbankan Dan Masalah Kredit Suatu Tinjauan Yuridis. Jakarta: Djambatan, 1996.

"PERLINDUNGAN HUKUM BAGI KREDITUR DALAM EKSEKUSI PERJANJIAN KREDIT DENGAN JAMINAN HAK TANGGUNGAN ATAS TANAH." LEX PRIVATUM (2020).

\section{Peraturan Perundang-undangan}

Kitab Undang-Undang Hukum Perdata, n.d. REPUBLIK INDONESIA. Undang-Undang Nomor 4 Tahun 1996 Tentang Hak Tanggungan Atas Tanah Beserta Benda-Benda Yang Berkaitan Dengan Tanah, 1996. 
Bank Indonesia. Peraturan Bank Indonesia Otoritas Jasa Keuangan (OJK). Peraturan (PBI) Nomor 14/15/PBI/2012 Tentang Otoritas Jasa Keuangan (POJK) Penilaian Kualitas Aset Bank Umum, Nomor 42 /POJK.03/2017 Tentang 2012.

Kewajiban Penyusunan Dan

Kementerian Keuangan. Peraturan Menteri Pelaksanaan Kebijakan Perkreditan Keuangan (PMK) Republik Indonesia Atau Pembiayaan Bank Bagi Bank Nomor 213/PMK.06/2020 Tentang Umum, 2017.

Petunjuk Pelaksanaan Lelang, 2020. 